\title{
KINERJA IMPLEMENTASI TATA KELOLA HUTAN TAMAN NASIONAL GUNUNG HALIMUN SALAK
}

\author{
Rita Rahmawati $^{1}$, Denny Hernawan ${ }^{1}$, Djoyo Sektiono ${ }^{1}$, dan Dudung Darusman ${ }^{2}$ \\ ${ }^{1}$ Jurusan Ilmu Administrasi Negara, Fakultas Ilmu Sosial dan Ilmu Politik, Universitas Djuanda \\ ${ }^{2}$ Fakultas Kehutanan Institut Pertanian Bogor \\ E-mail: rita.rahmawati@unida.ac.id
}

\begin{abstract}
ABSTRAK. Salah satu pekerjaan rumah yang harus diselesaikan dalam kaitannya dengan kebijakan tata kelola hutan di Indonesia adalah SK Menteri Kehutanan No.175 Tahun 2003. Namun, kebijakan tersebut tidak memperhatikan klaim dan persetujuan masyarakat yang sudah sejak lama tinggal dan bermukim di dalam/dekat dan disekitar kawasan hutan sehingga menimbulkan banyak permasalahan. Penelitian ini menggunakan indikator kinerja implementasi dari Bappenas (2007) dan metode penelitian deskriptif analisis. Hasilnya menunjukkan bahwa kebijakan perluasan tersebut cukup kompleks karena menimbulkan kerugian bagi pengelolaan maupun bagi masyarakat. Kerugian bagi pengelola terkait konflik dengan masyarakat lokal menyebabkan tidak semua program taman nasional dapat dijalankan, sedangkan masyarakat lokal mengalami kerugian yang nyata karena kehilangan hak akses untuk menggarap lahan pertanian yang masuk ke dalam kawasan hutan. Namun demikian, kebijakan perluasan taman nasional tersebut memberi manfaat bagi pengelolaan dan masyarakat disekitar kawasan.Manfaat bagi pengelola adalah semakin luasnya kawasan taman nasional sedangkan bagi masyarakat kaitannya dengan banyaknya program baru yang ditawarkan oleh pemerintah sebagai pengganti nafkah baru.
\end{abstract}

Kata kunci: Tata Kelola Hutan; Kinerja Implementasi; Kebijakan

\section{PERFORMANCE OF FOREST GOVERNANCE IMPLEMENTATION MOUNTAIN HALIMUN SALAK NATIONAL PARK}

\begin{abstract}
One of the homeworks that must be completed in relation to forest governance policies in Indonesia is the Ministerial Decree of the Indonesian Forestry Ministry No.175 Year of 2003. However, the policy does not seem to consider the claims and to comply with actual community agreements of the people living in and near the forest area. This has caused a few problems. This research refers to theory from the National Planning Board (Bappenas, 2007), and used a descriptive analysis method. The result showed that the expansion policy turns to be quite complex because it has both some disadvantages and also some advantages in forest management and for people living nearby. The disadvantages of forest management are related to conflict with local people. It has caused the national park programs were not to be run well, whereas local communities suffer significant losses due to less access to rights to cultivate agricultural land into forest areas. Nevertheless, the park's expansion policy has an advantage in forest management and people living nearby. The benefit for forest managers is the expansion of the national park area, while for local people, they have had a connection with many programs offered by the government as a replacement for a new livelihood.
\end{abstract}

Key words: Forest Administering Policies; Park Expansion Policy; Policy Performance

\section{PENDAHULUAN}

Indonesia dikenal sebagai negara yang memiliki beragam ekosistem yang salah satunya adalah hutan. Salah satu kawasan hutan di Indonesia yang merupakan hutan pelestarian alam adalah Taman Nasional Gunung Halimun Salak (TNGHS). Hutan TNGHS masih menyisakan masalah Kebijakan dalam tata kelola hutan dengan adanya SK Menteri Kehutanan No.175 Tahun 2003. Surat Keputusan ini menjadi dasar perluasan kawasan Gunung Halimun Salak, dengan merubah fungsi hutan, dari kawasan hutan lindung, hutan produksi tetap, hutan produksi terbatas menjadi kawasan Hutan Taman Nasional Gunung Halimun Salak, sehingga luas kawasan TNGHS menjadi seluas \pm 113.357 (seratus tiga belas ribu tiga ratus lima puluh tujuh) hektar yang berkedudukan di Provinsi Jawa Barat dan Provinsi Banten.

Perubahan fungsi hutan tersebut didasarkan atas adanya kekhawatiran akan nasib hutan di kelompok pegunungan Halimun Salak yang ditandai adanya aktivitas masyarakat lokal di sekitar hutan, yang dituduh menjadi penyebab deforestasi. Harapan berbagai pihak untuk menyelematkan kekayaan ekologi wilayah TNGHS ini menjadi salah satu pendorong terbitnya SK 175/2003.

Kebijakan perluasan dan perubahan fungsi hutan yang berubah menjadi hutan konservasi ini tentunya memberikan dampak terhadap pengelolaan hutan karena pada kawasan tertentu yang ditunjuk terdapat masyarakat lokal yang hidup dekat atau sekitar hutan, baik masyarakat adat maupun non adat.

Pemerintah Pusat dalam hal ini Menteri Kehutanan adalah pelaku kebijakan yang mengeluarkan Surat Keputusan Menteri Kehutanan Nomor 175/Kpts-II/2003 tanggal 10 juni 2003, namun implementasinya ada pada Balai Taman Nasional Gunung Halimun Salak (Balai TNGHS).

Surat Keputusan 175/2003, menyebabkan pengelolaan Taman Nasional Gunung Halimun Salak yang berada di bawah Balai Taman Nasional Gunung Halimun Salak mengalami penambahan luas, dari tadinya seluas 
\pm 40.000 Ha menjadi \pm 113.357 Ha. Hal ini berdampak pada permasalahan di Taman Nasional, terutama yang berkaitan dengan masalah kebijakan dan masalah-masalah lainnya. Permasalahan yang dihadapi Taman Nasional adalah sebagai berikut:

Kompleksitas Kebijakan. Perluasan dan perubahan fungsi hutan pada tataran implementasinya mengandung dimensi yang sangat kompleks. Ditinjau dari sisi kompleksitas suatu kebijakan, dalam proses implementasi SK Menteri Kehutanan No.175 Tahun 2003 ditemukan beberapa hal sebagai berikut: (1) Kebijakan perluasan Taman Nasional dan perubahan fungsi kawasan hutan lindung, hutan produksi tetap dan hutan produksi terbatas menjadi hutan konservasi ini tidak memperhatikan masalah yang akan timbul dan mengabaikan klaim atas hutan oleh masyarakat adat (2) Kebijakan perluasan dan perubahan fungsi TNGHS ini juga tidak memperhatikan masyarakat kurang mampu yang sudah sejak lama tinggal dan menggantungkan hidupnya di kawasan TNGHS tersebut. Sepintas kebijakan perluasan taman nasional ini menuai masalah baru, dibandingkan mengatasi masalah yang ada.

Kebijakan mestinya merupakan tindakan untuk mengatasi masalah, sebagaimana dikemukakan oleh Asep Tapip (2012) bahwa Kebijakan merupakan serangkaian keputusan yang dirumuskan untuk mengarahkan tindakan dalam memecahkan masalah agar memenuhi tujuan tertentu yang telah ditetapkan. (Yani, 2012)

Tujuan perluasan dari Taman Nasional adalah untuk melestarikan hutan dengan merubah status hutan produksi menjadi hutan konservasi, namun tidak dapat dipungkiri bahwa di kawasan tersebut hidup masyarakat yang turut menggarap hutan produksi, sehingga kebijakan untuk mengatasi masalah pelestarian hutan menuai masalah baru dalam kehidupan masyarakat lokal.

Persepsi Tentang Manfaat Kebijakan. Persepsi tentang manfaat kebijakan yaitu harapan terhadap semua bentuk keuntungan dan nilai-nilai positif yang akan dirasakan langsung maupun tidak langsung, sebagai dampak dari pelaksanaan kebijakan pengelolaan hutan dengan sistem zonasi yang mengalami perluasan dan perubahan fungsi hutan. Persepsi tersebut berhubungan dengan manfaat kebijakan bagi stakeholders dan masyarakat yang berada di wilayah sampel studi (Desa Sirnaresmi dan Desa Cipeteuy). Dalam hal ini, stakeholder diwakili oleh pegawai balai TNGHS. Pegawai balai TNGHS adalah stakeholder yang pertama terkena dampak kebijakan disamping masyarakat lokal. Selain itu, Pegawai balai TNGHS harus berhadapan dengan masyarakat dalam menjalankan kebijakan Pemerintah.

Kebijakan Menteri Kehutanan tentang perluasan dan perubahan fungsi ini diharapkan mampu menyelematkan fungsi, kekayaan sumber daya alam dan kekayaan ekologi yang ada di wilayah TNGHS. Namun, munculnya persepsi negatif terhadap kebijakan tata kelola hutan yang mengalami perluasan dan perubahan fungsi ini tentunya menjadi masalah bagi Balai TNGHS dalam mengelola hutan TNGHS.

Masalah pengelolaan TNGHS muncul mengingat masyarakat lokal yang tadinya berada diluar kawasan menjadi berada di dalam kawasan. Ada dua jenis masyarakat yang tinggal di dalam kawasan, yaitu masyarakat adat Kasepuhan dan masyarakat non adat. Masyarakat adat mengklaim bahwa kawasan tersebut merupakan hutan milik adat. Mereka sudah ada di lokasi sebelum TNGHS ada. Perjuangan masyarakat adat untuk memperoleh pengakuan hak ulayat ini dilakukan melalui Pemerintah Daerah dan mendorong Pemerintah Daerah untuk mengeluarkan Peraturan Daerah (Perda).

Kemampuan Sumber Daya Manusia (SDM). Kemampuan SDM Balai Taman Nasional Gunung Halimun Salak dianalisa dari komitmen dan kemampuan Balai TNGHS dalam melaksanakan tugas, serta bentuk dukungan yang dimilikinya untuk menjalankan tugas tersebut. Bentuk komitmen Balai TNGHS diamati dari ada atau tidaknya program instansi terkait dalam tata kelola hutan sesuai tugasnya, sedangkan bentuk kemampuan Balai TNGHS diamati dari pengaruh ketepatan / efektifitas pelaksanaan tugasnya atau tingkat pencapaian optimalitas dalam pelaksanaan tugas.

Kemampuan Sumber daya manusia yang belum siap dengan mengelola hutan yang mengalami perluasan dan perubahan fungsi tentunya menghambat proses tata kelola hutan. Hal ini ditunjukkan bahwa jumlah hutan Taman Nasional seluas 113.357 ha hanya diawasi oleh 42 orang polisi kehutanan yang bertugas mengawasi hutan dan 105 orang yang bertugas di berbagai urusan kehutanan.

Otoritas dan Diskresi. Otoritas adalah kewenangan dan keleluasaan yang dimiliki Balai TNGHS dalam mengimplementasikan keputusan yang telah dikeluarkan oleh Menteri Kehutanan. Hutan TNGHS, sesuai dengan UU No.5 Tahun 1990 tentang tata ruang, TNGHS termasuk kategosi kawasan lindung. Sebagai kawasan lindung, TNGHS mestinya bebas dari aktivitas masyarakat. Meskipun demikian, kawasan TNGHS juga masuk ke dalam wilayah administrasi Pemerintah Daerah Pro-vinsi, Kabupaten, Kecamatan dan Desa, dimana di daerah ini hidup masyarakat. Keberadaan masyarakat di TNGHS diatur melalui regulasi pemerintah daerah dan memperoleh pengakuan legal dengan kepemilikan KTP. Ada 314 kampung yang masuk dalam kawasan TNGHS. Keberadaan masyarakat dan kampung-kampung dalam kawasan TNGHS ini berpotensi menjadi penghambat dan pendukung keberadaan TNGHS.

Masyarakat yang hidup di wilayah TNGHS menghadapi dua otoritas, otoritas legal melalui Pemerintahan 
Daerah (Desa) dan otoritas adat. Otoritas kepala adat ini juga menjadi kendala tata kelola hutan di kawasan TNGHS. Otoritas dan diskresi kepala adat membuat kewenangan dalam memanfaatkan sumber daya hutan sehingga proses tata kelola hutan oleh pemerintah terhambat oleh otoritas kepala adat.

Geografis. Penelitian ini dilakukan di kawasan hutan Taman Nasional Gunung Halimun Salak. Istilah "Kawasan Hutan", sudah diperkenalkan dan dibakukan sejak diundangkan Undang-Undang Nomor 5 Tahun 1967 tentang ketentuan-ketentuan pokok kehutanan (LNRI1967-8,TLN-2823). Tepatnya dalam pasal 1 ayat 4 yang memberi batasan bahwa: "kawasan hutan" ialah wilayahwilayah tertentu yang oleh Menteri ditetapkan untuk dipertahankan sebagai hutan tetap". (Subadi, 2010).

Namun setelah Undang-Undang tersebut diganti dengan Undang-Undang No.41 Tahun 1999 tentang Kehutanan (LNRI-1999-167,TLNRI-3587). Batasan mengenai pengertian kawasan hutan ini telah mengalami sedikit perubahan sebagaimana diatur dalam pasal 1 ayat 3 yang menyatakan; "kawasan hutan" adalah wilayah tertentu yang ditunjuk da/ditetapkan oleh pemerintah untuk dipertahankan keberadaanya sebagai hutan tetap"(Subadi, 2010).

Berdasarkan pembatasan tersebut, maka ada beberapa unsur yang melekat pada pengertian kawasan hutan yaitu: a. Wilayah tertentu, maksud dari wilayah ini adalah daerah/areal baik yang telah berhutan atau yang belum/tidak berhutan dan bahkan termasuk yang telah mengalami deforestrasi maupun degradasi; b. Ditunjuk dan atau ditetapkan oleh Pemerintah; c. Dipertahankan sebagai hutan tetap (Subadi, 2010).

Kawasan hutan yang dimaksud dalam tulisan ini menurut pasal 1 Undang-Undang Nomor 41 Tahun 1999 tentang Kehutanan (LNRI-1999-167,TLNRI-3587), dapat dijelaskan sebagai berikut: a. Hutan produksi; b. Hutan lindung; c. Hutan konservasi; d. Kawasan hutan suaka alam; e. Kawasan hutan pelestarian alam adalah hutan dengan ciri khas tertentu, yang mempunyai fungsi pokok perlindungan sistem penyangga kehidupan, pengawetan keanekaragaman jenis tumbuhan dan satwa serta pemanfaatan secara lestari sumber daya alam hayati dan ekosistemnya. Taman nasional Gunung Halimun Salak adalah Taman nasional yang merupakan kawasan hutan pelestarian alam.

Budaya. Masyarakat lokal yang tinggal di sekitar dan dalam kawasan TNGHS, salah satunya adalah masyarakat adat Kasepuhan. Masyarakat ini hidup dalam tradisi budaya yang khas. Keberadaan masyarakat adat ini menjadi tantangan tersendiri bagi TNGHS, mengingat kebiasaan hidup masyarakat yang sangat tergantung dari wangsit. Wangsit adalah instruksi dari roh nenek moyang yang diterima melalui mimpi. (Rahmawati, Salbiah, \&
Pratidina, 2016). Berdasarkan wangsit tersebut, masyarakat adat berpindah-pindah dan menetap di suatu lokasi, sehingga terdapat beberapa kampung adat kasepuhan yang berada di dalam kawasan TNGHS.

\section{METODE}

Pendekatan penelitian ini adalah Deskriptif. Penelitian deskriptif adalah penelitian yang dilakukan untuk mengetahui nilai variabel mandiri, baik satu variabel atau lebih (independen) tanpa membuat perbandingan atau menghubungkan antara variabel yang lain. (Sugiyono, 2013).

Metode penelitian deskriptif digunakan untuk mengetahui permasalahan dengan cara menguraikan secara rinci dan jelas serta dilakukan untuk menganalisis data mengenai gejala-gejala yang berhubungan dengan Implementasi Kebijakan oleh Balai TNGHS dalam mengelola hutan Taman Nasional Gunung Halimun Salak, sehingga dapat diketahui masalahnya dan berusaha mencari solusinya.

Populasi penelitian ini berasal dari dua sumber yaitu pegawai Balai TNGHS (Kantor Pusat dan Kantor Seksi Wilayah III Sukabumi) yang berjumlah 45 orang dan masyarakat lokal yang tinggal di sekitar kawasan TNGHS yang mewakili masyarakat adat dan non adat yaitu Desa Adat Sirnaresmi (Kasepuhan Sinarresmi) dan Desa Cipeutey (Kp. Sukagalih). Adapun untuk sampling yang diambil dari pegawai Balai TNGHS digunakan Disproportionate Stratified Random Sampling. Untuk penentuan jumlah sampel digunakan rumus yamane dalam Sukandarrumidi (2012-56) dengan tingkat kesalahan (margin eror) 10\% maka dengan populasi 45 orang diperoleh ukuran sampel 31 orang.

Teknik sampling yang digunakan dalam penelitian ini adalah purposive sampling, dengan pertimbangan bahwa masyarakat lokal yang berada di dalam dan sekitar kawasan TNGHS terbagi dalam dua karakteristik yaitu masyarakat Kasepuhan dan non Kasepuhan. Setiap kelompok masyarakat memiliki karakter nilai budaya, sikap, persepsi dan keputusan yang sama yang digerakkan oleh pemimpin adat mereka. Namun pengetahuan dari setiap anggota kelompok masyarakat tersebut berbeda. Pemilihan teknik purposive dilakukan kepada anggota masyarakat yang memiliki pengetahuan tentang tata kelola hutan dan bisa mewakili seluruh karakteristik anggota masyarakat yang ada.

Pengumpulan data dalam penelitian ini dilakukan melalui: (a) Studi Kepustakaan, (b) Studi Lapangan melalui (1) Observasi, (2) Wawancara (Pegawai Balai TNGHS dan Masyarakat Desa Sirnaresmi dan Desa Cipeutey), (3) Kuesioner (31 orang Pegawai Balai TNGHS, 40 Masyarakat Adat Kasepuhan Sinar Resmi, dan 40 Masyarakat Non Adat Kp.Sukagalih Desa Cipeutey). 
Data yang digunakan dalam penelitian ini adalah (1) Data primer (data yang diperoleh secara langsung dari Balai TNGHS dan Masyarakat ), (2) Data sekunder (data yang diperoleh dari dokumen dan arsip-arsip Balai TNGHS). Selanjutnya data diolah berdasarkan hasil jawaban responden melalui kuesioner dengan menggunakan rumus WMS (Weight Mean Score). (Siregar, 1993)

\section{HASIL DAN PEMBAHASAN}

\section{Taman Nasional Gunung Halimun Salak (TNGHS)}

Secara administratif wilayah kerja TNGHS berada pada tiga wilayah administratif Pemerintahan Kabupaten yaitu Bogor, Sukabumi dan Lebak, yang terdiri dari 28 Kecamatan dan 114 desa: Kabupaten Bogor (9 Kecamatan), Kabupaten Sukabumi, dan Kabupaten Lebak (11 Kecamatan).

Lokasi penelitian berada di dua desa, terdiri dari desa yang mewakili desa adat yaitu Desa Sirnaresmi (Kasepuhan Sinarresmi) dan desa yang mewakili desa non adat yaitu Desa Cipeutey (Khususnya Kampung Sukagalih).

\section{Kondisi Kelembagaan}

Kelembagaan yang ada di wilayah taman nasional TNGHS terdiri atas: kelembagaan Balai TNGHS, kelembagaan masyarakat lokal, kelembagaan Perusahaan yang berdomisili dan atau melakukan aktivitas di TNGHS antara lain Perusahaan dengan sarana sutetnya, kelembagaan pembangkit listrik panas bumi, kelembagaan aktivitas pertambangan emas, kelembagaan perkebunan. Namun kelembagaan perusahaan (baik tambang maupun perkebunan) sudah memiliki MOU tersendiri dengan BTNGHS, sehingga kebijakan perluasan taman nasional tidak berdampak secara signifikan terhadap perusahaan perusahaan tersebut. Peran kelembagaan yang paling signifikan dalam menjalankan kebijakan perluasan taman nasional adalah Balai TNGHS. Kelembagaan yang dimaksud dalam penelitian ini adalah Balai TNGHS.

Balai TNGHS mempunyai tugas pokok melaksanakan pengelolaan Taman Nasional Gunung Halimun Salak sesuai dengan prinsip-prinsip konservasi dan berdasarkan peraturan perundangan yang berlaku. Berdasarkan Peraturan Menteri Kehutanan No. P.03/MenhutII/2007 tanggal 1 Februari 2007 tentang Organisasi dan Tata Kerja Unit Pelaksana Teknis Taman Nasional, Balai TNGHS adalah organisasi yang berada di bawah dan bertanggung jawab langsung kepada Direktorat Jenderal Perlindungan Hutan dan Konservasi Alam. Balai TNGHS (BTNGHS) mempunyai fungsi sebagai berikut: (1) Melakukan penyusunan program pengembangan TNGHS, (2) Melakukan pemangkuan kawasan, perlindungan, pengawetan dan pelestarian flora fauna dan ekositemnya, (3) melaksanakan pemanfaatan dan promosi serta memberikan informasi mengenai TNGHS, (4) melakukan urusan tata usaha (Balai Taman Nasional Gunung Halimun Salak, 2014).

BTNGHS adalah taman nasional tipe B yang memiliki 1 (satu) orang kepala balai setingkat eselon III.a ditambah 1 (satu) orang kepala sub bagian tata usaha setingkat eselon IV.a serta 3 (tiga) orang kepala seksi wilayah setingkat eselon IV.a, serta kelompok jabatan fungsional yang terdiri dari polisi kehutanan (Polhut), Pengendali Ekosistem Hutan, dan Penyuluh Kehutanan.

BTNGHS selaku pengelola TNGHS memiliki kegiatan-kegiatan pengelolaan yang dapat dibagi dalam tiga kelompok, yaitu manajemen kawasan; manajemen sumberdaya alam; serta manajemen kelembagaan. BTNGHS sebagai badan pelaksana taman nasional memberikan keuntungan dan pembatasan pada masyarakat local. Hal ini sebagaimana dikemukakan oleh Winarno (2014) bahwa badan pelaksana memberikan keuntungan atau pembatasan kepada para pelanggan atau kelompokkelompok target. Mereka juga memberikan pelayanan atau pembayaran atau batasan-batasan tentang kegiatan atau apapun lainnya yang bisa dipandang sebagai wujud dari keluaran yang nyata dari suatu program (Winarno, 2014). Dengan begitu BTNGHS tidak dapat melepaskan diri dari keberadaan masyarakat tersebut, bahkan beberapa program BTNGHS dijalankan dengan melibatkan keberadaan masyarakat.

\section{Kondisi Sosial, Budaya dan Ekonomi Masyarakat}

Menurut Balai TNGHS (2014), Masyarakat lokal yang tinggal dan bermukim di dalam dan disekitar TNGHS pada umumnya adalah suku sunda, yang terbagi ke dalam masyarakat kasepuhan (adat) dan bukan kasepuhan (Non adat). Masyarakat adat yang tinggal di kawasan TNGHS merupakan menganut tradisi kasepuhan; suatu tradisi masyarakat yang bertumpu pada ekoreligi padi (Adimiharja, 1992).

Masyarakat kasepuhan memiliki susunan organisasi secara adat yang terpisah dari struktur organisasi pemerintah formal (desa). Komunitas kasepuhan dipimpin oleh seorang "sesepuh" yang dipanggil dengan sebutan abah, olot atau ama. Komunitas yang ada di TNGHS Antara lain: Kasepuhan Ciptagelar, Sirnaresmi, Ciptamulya, Cisitu, Cisungsang, Ciusul, Cibedug, Citorek, Urug, Cicacurub, Bayah dan Giri Jaya (Balai Taman Nasional Gunung Halimun Salak, 2014).

Masyarakat Kasepuhan dicirikan dengan masih kuatnya tradisi bergotong royong termasuk dalam pengelolaan pertanian. Sawah memiliki nilai penting dalam kehidupan masyarakat. Dalam system pertaniannya dikenal ada beberapa tradisi adat, salah satunya adalah tradisi seren tahun (pesta panen tahunan) setiap tahunnya. Keberadaan 
jenis-jenis padi khas Masyarakat Kasepuhan menandai pentingnya beras bukan hanya sebagai bahan makanan pokok tetapi bagian dari tradisi dan rasa syukur kepada Tuhan penguasa padi.

Ada beberapa cara yang dilakukan oleh Masyarakat lokal dalam pemanfaatan hutan TNGHS, yaitu sebagai huma/ladang; sawah; kebun; talun dan kebun campuran. Masyarakatkasepuhanmempunyainilai-nilaikearifanlokal yang diwariskan secara turun temurun dalam pemanfaatan dan konservasi hutan. Masyarakat Kasepuhan membagi wilayah hutan dalam beberapa zonasi/ wewengkon, yaitu: leuweung titipan, leuweung tutupan, leuweung cawisan dan leuweung garapan.(Rahmawati, 2013). Masyarakat Kasepuhan juga memiliki pengetahuan tentang berbagai jenis tanaman obat.(Rahmawati, Rita et al., 2016).

Kemampuan ekonomi masyarakat sekitar TNGHS cenderung rendah, namun sebagian besar tidak termasuk dalam kategori rumah tangga (RT) miskin. Kehidupan rumah tangganya bergantung pada mata pencaharian pertanian padi sebagai mata pencaharian utama. Disamping pertanian padi, masyarakat local juga menanam tanaman palawija dan tanaman lainnya. Tanaman padi tidak boleh dijual, hanya untuk dikonsumsi sendiri, sedangkan tanaman lainnya boleh dijual. Hasil penjualan tanaman lainnya inilah yang menjad sumber keuaangan untuk membeli kebutuhan lauk pauk maupun kebutuhn lainnya.

Masyarakat lokal adalah masyarakat yang hidup di lingkungan dan di dalam kawasan Taman Nasional Gunung Halimun Salak baik yang termasuk masyarakat adat Kasepuhan maupun non adat kasepuhan. Rata-rata masyarakat yang tinggal di Kawasan Gunung Halimun merupakan masyarakat miskin. Karakteristik ini terlihat dari sebagian besar rumah yang terbuat dari bilik dan berlantai tanah. Sekalipun demikian, melihat dari beberapa kondisi keluarga seperti kebiasaan makan, ketersediaan pakaian, pendidikan anak, masyarakat di kawasan ini telah memilki kondisi yang baik, yaitu makan minimal 2 kali sehari dan tercukupi pakaian serta anak-anak dapat bersekolah. Hal ini menggambarkan masyarakat yang aktif dan produktif. Tingkat Aktifitas masyarakat dibuktikan dengan lebih dari $90 \%$ responden ikut aktif dalam kegiatan sosial masyarakat. (Rahmawati, Pratidina, dan Muarif, 2011).

Dalam Zonasi TNGHS Tahun 2012 disebutkan bahwa degradasi ekosistem hutan yang dilakukan masyarakat banyak terjadi di desa-desa yang berada di dalam dan sekitar kawasan TNGHS dan diduga terkait erat dengan rendahnya kemampuan ekonomi masyarakat. Sumber penghidupan masyarakat sangat didominasi dari sektor pertanian dan perkebunan sedangkan sumber penghidupan sebagian masyarakat lainnya dari kegiatan pertambangan ilegal (PETI) serta penyadapan pinus dan damar.

\section{Kinerja Implementasi Kebijakan Tata Kelola Hutan Taman Nasional Gunung Halimun Salak}

Istilah implementasi menunjuk pada sejumlah kegiatan yang mengikuti pernyataan tentang tujuan-tujuan program dan hasil-hasil yang diinginkan oleh para pejabat pemerintah. Implementasi mencakup tindakan-tindakan (tanpa tindakan-tindakan) oleh berbagai aktor khususnya para birokrat, yang dimaksudkan untuk membuat program berjalan (Winarno, 2014).

Implementasi mencakup banyak macam kegiatan. Pertama badan-badan pelaksana yang ditugasi oleh undang-undang dengan tanggung jawab menjalankan program harus mendapatkan sumber-sumber yang dibutuhkan agar implementasi berjalan lancar. Sumbersumber ini meliputi personil, peralatan, lahan tanah, bahan-bahan mentah, dan diatas semuanya. Kedua, badanbadan pelaksana mengembangkan bahasa anggaran dasar menjadi arahan-arahan konkret, regulasi, serta rencanarencana desain program. Ketiga, badan-badan pelaksana harus mengorganisasikan kegiatan-kegiatan mereka dengan menciptakan unit-unit birokrasi dan rutinitas untuk mengatasi beban kerja. Akhirnya, badan-badan pelaksana memberikan keuntungan atau pembatasan kepada para pelanggan atau kelompok-kelompok target. Mereka juga memberikan pelayanan atau pembayaran atau batasanbatasan tentang kegiatan atau apapun lainnya yang bisa dipandang sebagai wujud dari keluaran yang nyata dari suatu program (Winarno, 2014).

Sementara itu Grindle (1980) memberikan pandangannya tentang implementasi dengan mengatakan bahwa secara umum, tugas impelementasi adalah membentuk suatu kaitan (linkage) yang memudahkan tujuan-tujuan kebijakan bisa direalisasikan sebagai dampak dari suatu kegiatan pemerintah (Grindle, 1980). Oleh karena itu, tugas implementasi mencakup terbentuknya "a policy delivery system", dimana sarana-sarana tertentu dirancang dan dijalankan dengan harapan sampai pada tujuan-tujuan yang diinginkan.

Apa yang disampaikan Grindle tersebut juga disampaikan kembali oleh Erwan Agus Purwanto dan Dyah Ratih Sulistyastuti (2012;21) bahwa Implementasi adalah "kegiatan untuk mendistribusikan keluaran kebijakan (to deliver policy output) yang dilakukan oleh para implementor kepada kelompok sasaran (target group) sebagai upaya untuk mewujudkan tujuan kebijakan". (Purwanto \& Sulistyastuti., 2012).

Dengan demikian sebuah kebijakan baru dapat diimplementasikan setelah tujuan dan sasaran ditetapkan, program kegiatan telah tersusun dan dana telah siap. Implementasi dilakukan untuk mendistribusikan kebijakan. William N. Dun (2003: 44) mendefinisikan implementasi kebijakan sebagai pelaksanaan pengendalian aksi-aksi kebijakan di dalam kurun waktu tertentu (Dunn, 2003). 
Artinya pendistribusian kebijakan tersebut dibatasi oleh waktu dan koridor pengendalian, untuk memastikan kebijakan berhasil diimplementasikan.

Berhasil tidaknya sebuah kebijakan diimplementasikan dapat diukur melalui kinerja implementasi kebijakan. Selanjutnya menurut Merille S.Grindle (1980) bahwa faktor penentu kinerja implementasi kebijakan ditentukan faktor penentu seperti: kepentingan yang dipengaruhi, tipe keuntungan yang diharapkan, cakupan perubahan yang diupayakan, situs pembuatan keputusan, implementor program, dan sumberdaya yang tersedia (Bappenas, 2007).

Menurut Bappenas (2007) ada 3 poin pentinga dalam memahami kinerja implementasi kebijakan, yaitu: faktor kebijakan, kapasitas organisasi dan faktor lingkungan (Bappenas, 2007). Ketiga faktor tersebut dijadikan pedoman untuk menilai kinerja implementasi kebijakan tata kelola hutan Taman Nasional Gunung Halimun Salak. Oleh karena itu, dalam mengkaji kinerja implementasi keijakan Taman Nasional Gunung Halimun Salak, dibagi kedalam tiga kelompok variabel: (A) Faktor Kebijakan, (B) Kapasitas Kelembagaan, (C) Lingkungan. Tiga kelompok variabel tersebut dijelaskan ke dalam beberapa sub variabel seperti berikut:

(A) Faktor Kebijakan, terdiri dari: Kompleksitas Kebijakan dan Persepsi Manfaat Kebijakan

(B) Kapasitas Kelembagaan, terdiri dari: Kapasitas SDM dan Otoritas dan Diskresi

(C) Lingkungan, terdiri dari: Georgafis dan Sosial Budaya

Adapun Hasil Rekapitulasi pada setiap dimensi variabel Implementasi Kebijakan dari setiap tanggapan Pelaksana maupun masyarakat adat dan non adat yang dapat dilihat pada tabel-tabel berikut ini :

Tabel 1. Penilai Pelaksana Atas Tata Kelola Hutan TNGHS

\begin{tabular}{lcc}
\hline \multicolumn{1}{c}{ Dimensi } & M & Kriteria Penilaian \\
\hline Faktor Kebijakan & 3,41 & Cukup Baik \\
Kapasitas Organisasi & 3,35 & Cukup Baik \\
Faktor Lingkungan & 3,16 & Cukup Baik \\
\hline Rekapitulasi Dimensi & $\mathbf{3 , 3 2}$ & Cukup \\
\hline
\end{tabular}

Dari perolehan angka penilaian dalam tabel 4.41 menunjukan skor 4.90 maka dapat dilakukan penafsiran bahwa Implementasi Kebijakan TataKelolaHutan TNGHS pada dimensi faktor kebijakan, kapasitas organisasi dan faktor lingkungan berada pada kategori cukup baik. hal ini diperkuat dengan hasil wawancara yang mengatakan bahwa dalam mengimplementasikan kebijakan tata kelola hutan taman nasional yang mengalami perluasan bukanlah hal yang mudah karena setelah dikeluarkanya SK Menteri Kehutanan tersebut, Balai TNGHS mengemban tugas yang cukup berat dalam pengelolaan hutan.
Sistem pengelolaan hutan seharusnya memberikan kesejahteraan bagi masyarakatnya, sebagaimana dikemukakan oleh Feni Rosalia dan Yuni Ratnasari (2016) bahwa system pengelolaan hutan bertujuan untuk memberdayakan masyarakat (meningkatkan nilai ekonomi, nilai budaya, memberikan manfaat/benefit kepada masyarakat pengelola, dan masyarakat setempat), tanpa mengganggu fungsi pokoknya (meningkatkan fungsi hutan dan fungsi kawasan, pemanfaatan kawasan, pemanfaatan jasa lingkungan, pemanfaatan hasil hutan kayu, pemanfaatan hasil hutan bukan kayu dengan tetap menjaga fungsi kawasan hutan). (Rosalia \& Ratnasari, 2016).

Namun faktanya justru di Taman Nasional Gunung Halimun Salak. Sistem pengelolaan hutan taman nasional dengan merujuk pada kebijakan Menteri Kehutanan No. 175 Tahun 2003, justru menimbulkan permasalahan. Permasalahan ini terjadi dikarenakan perbedaan tupoksi antara Balai TNGHS dengan PERUM PERHUTANI. Kebijakan tersebut bisa dikatakan cukup kompleks karena terdapat cukup banyak permasalahan dan kurang memperhatikan kapasitas organisasi dan lingkungan sekitar sehingga menurut pelaksana, dalam mengimplementasikan kebijakan tata kelola hutan yang mengalami perluasan sejauh ini sudah cukup baik namun masih ada permasalahan-permasalahan yang harus diselesaikan.

Berdasarkan tabel 2 diketahui bahwa perolehan angka penilaian menunjukan skor 2,59, dengan penafsiran bahwa Implementasi Kebijakan Tata Kelola Hutan TNGHS pada dimensi faktor kebijakan, kapasitas organisasi dan faktor lingkungan menurut masyarakat non adat berada pada kategori kurang baik.

Tabel 2. Penilaian Masyarakat Adat Atas Tata Kelola Hutan TNGHS

\begin{tabular}{lcc}
\hline \multicolumn{1}{c}{ Dimensi } & M & Kriteria Penilaian \\
\hline Faktor Kebijakan & 2,41 & Kurang Baik \\
Kapasitas Organisasi & 2,53 & Kurang Baik \\
Faktor Lingkungan & 2,92 & Cukup Baik \\
\hline Rekapitulasi Dimensi & $\mathbf{2 , 5 9}$ & Kurang Baik \\
\hline
\end{tabular}

Sumber: Hasil Penelitian 2015

Diperkuat dengan hasil wawancara dengan masyarakat adat yang mengatakan bahwa Balai TNGHS belum mampu mengimplementasikan kebijakan tata kelola hutan taman nasional yang mengalami perluasan tersebut dengan baik. Hal ini dikarenakan terdapat banyak permasalahan yang terjadi sampai saat ini diantaranya kurang harmonisnya hubungan Balai TNGHS dengan Masyarakat adat. Hal ini dikarenakan kurang adanya kordinasi dan komunikasi yang baik antara kedua pihak. Hal tersebut dikarenakan perbedaan pendapat dimana 
aturan yang berlaku dalam pengelolan hutan menurut aturan negara khusunya aturan konservasi dan menurut aturan adat.

Tabel 3. Penilaian Masyarakat Non Adat Atas Tata Kelola Hutan TNGHS

\begin{tabular}{lcc}
\hline \multicolumn{1}{c}{ Dimensi } & M & Kriteria Penilaian \\
\hline Faktor Kebijakan & 3,56 & Baik \\
Kapasitas Organisasi & 3,44 & Baik \\
Faktor Lingkungan & 3,86 & Baik \\
\hline Rekapitulasi Dimensi & $\mathbf{3 , 5 8}$ & Baik \\
\hline
\end{tabular}

Sumber: Hasil Penelitian 2015

Dari perolehan angka penilaian dalam tabel menunjukan skor 3,58 maka dapat dilakukan penafsiran bahwa Implementasi Kebijakan Tata Kelola Hutan TNGHS pada dimensi faktor kebijakan, kapasitas organisasi dan faktor lingkungan menurut masyarakat non adat berada pada kategori baik. hal ini diperkuat dengan hasil wawancara yang mengatakan bahwa sejauh ini Balai TNGHS dapat mengimplementasikan kebijakan tata kelola hutan yang mengalami perluasan dengan baik.menurut mereka, Balai TNGHS memberikan alternatif lain terhadap kerugian yang mereka terima yaitu seperti progam Model Kampung Konservasi (MKK). Program ini diluncurkan setelah adanya kebijakan perluasan sehingga memberikan manfaat sosial ekonomi bagi masyarakat seperti banyak peneliti dan wisatawan yang datang ke kampung mereka sehingga memberikan tambahan penghasilan. Adapun kondisi hutan yang semakin lebat membuat kondisi air bagus dan tidak kekeringan. Adapun rata-rata rekapitulasi variabel implementasi kebijakan:

Tabel 4. Rata-Rata Skor Penilaian Tata Kelola Hutan TNGHS

\begin{tabular}{ccc}
\hline $\begin{array}{c}\text { Menurut } \\
\text { Pelaksana }\end{array}$ & $\begin{array}{c}\text { Menurut } \\
\text { Masyarakat Adat }\end{array}$ & $\begin{array}{c}\text { Menurut } \\
\text { Masyarakat Non Adat }\end{array}$ \\
\hline 3,32 & 2,59 & 3,58 \\
\hline
\end{tabular}

Sumber : Hasil Penelitian 2015

Adapun Dari perolehan angka penilaian menurut pelaksana, masyarakat adat dan masyarakat non adat dalam tabel 4.93 menunjukan perbedaan skor dimana hasil rekapitulasi implementasi kebijakan menurut pelaksana menunjukan skor 3,32, sedangkan masyarakat adat menunjukan skor 2,58 dan adapun masyarakat non adat yang menunjukan skor 3,58 maka dapat dilakukan penafsiran bahwa titik kelemahan dari implementasi kebijakan tata kelola hutan TNGHS terletak pada (1) kerugian kebijakan bagi masyarakat, (2) jumlah SDM Balai TNGHS, (3) kemampuan Balai TNGHS dalam mengatasi otoritas lembaga lokal, dan (4) Hambatan Geografis.

Titik kelemahan dari implementasi kebijakan yang pertama terletak pada faktor kebijakan yang merugikan masyarakat, khususnya masyarakat yang sudah sejak lama tinggal dan bermukin di dekat dan sekitar kawasan hutan yang memiliki ketergantungan pada hutan. Adapun jumlah SDM Balai TNGHS yang belum sesuai dengan kebutuhan menyebabkan tidak efektifnya kinerja implementasi kebijakan tata kelola hutan TNGHS. Lebih lanjut, kemampuan Balai TNGHS dalam mengatasi otoritas lembaga lokal juga menjadi hambatan karena saat ini implementator belum mampu mengatasi otoritas / kewenangan kepala adat . situasi geografis yang berada di tiga wilayah administratif pemerintahan juga menjadi salah satu titik kelemahan dalam mengimplementasikan kebijakan.

\section{Faktor-Faktor Yang Menentukan Kinerja Implementasi Kebijakan}

Ditinjau dari dimensi Faktor Kebijakan yang terdiri dari Kompleksitas Kebijakan, dan Persepsi Manfaat Kebijakan, dimana dimensi Kapasitas Organisasi terdiri atas indikator SDM \& Otoritas dan Diskresi, sedangkan dimensi Faktor Lingkungan terdiri atas indikator Geografis dan Budaya, diketahui ada beberapa faktor pendukung dan penghambat kinerja implementasi kebijakan TNGHS. Faktor pendukung dari kinerja implementasi kebijakan adalah:

1. Indikator kompleksitas kebijakan: Pemberian Kewenangan kepada Balai Taman Nasional Gunung Halimun Salak dengan tujuan untuk menekan angka kerusakan hutan dengan merubah cara pengelolaan hutan menjadi pengelolaan hutan konservasi

2. Indikator persepsi manfaat kebijakan: bagi pengelolaan memberi manfaat untuk mencegah kerusakan hutan dan memulihkan kembali kawasan hutan yang mengalami kerusakan.

Kesamaan persepsi ini akan memberikan interpretasi yang sama akan tujuan dan manfaat kebijakan. Selanjutnya interpretasi yang benar akan mengarah pada adanya kesadaran bersama mengenai pentingnya kebijakan tersebut dan dianggap bahwa kebijakan memberi manfaat bagi semua pihak. Temuan ini sejalan dengan apa yang dikemukakan oleh Diah Fatma Sjoraida (2015) bahwa intepretasi yang benar dari tujuan kebijakan (dalam hal ini kebijakan keterbukaan informasi publik) seharusnya dapat menghasilkan kesadaran bersama mengenai urgensi pencapaian tujuan pelaksanaan kebijakan. Kesadaran bersama di kalangan pemerintah akan menghasilkan suatu bentuk konsensus dan komitmen yang mempengaruhi konsistensi dalam bersikap, dan pada akhirnya membentuk budaya yang akan memperkuat organisasi pemerintah dan terlaksananya kebijakan secara efektif.(Sjoraida, Diah Fatma, 2015).

Dalam kaitannya dengan penelitian ini, konsensus yang dimaksud adalah consensus untuk menjaga 
dan mengamankan ekosistem sumberdaya hutan dan menyelamatkan hewan-hewan langka dari perburuan liar. Dalam penelitian ini bedanya consensus bukan hanya dibangun diantara organisasi Pemerintah, melainkan Pemerintah dan Masyarakat.

Bagi Masyarakat kesadaran untuk mendukung program Pemerintah melahirkan manfaat lain, antara lain adanya bantuan untuk peningkatan kapasitas ekonomi masyarakat lokal berupa pelatihan dan bantuan kambing untuk mewujudkan nafkah baru yang tidak merusak hutan, pembangunan MCK, penyediaan pupuk, bibit padi dll. Adapun manfaat lain yang diberikan adalah diikutsertakan MOU antara Balai TNGHS dan Pihak Swasta. Selain itu kebijakan tersebut juga memotivasi masyarakat untuk berpendidikan tinggi dikarenakan banyak peneliti yang datang ke kawasan hutan yang mengalami perluasan. Para peneliti tersebut memberikan ilmu yang sangat bermanfaat bagi masyarakat. Adapun manfaat lain berupa penghasilan tambahan dari rumahrumah mereka yang dijadikan homestay dan disewa oleh peneliti maupun wisatawan. Manfaat yang paling terasa adalah kondisi air yang bagus dan tidak kekeringan sehingga sawah mereka subur.

3. Indikator SDM: Balai TNGHS memiliki kualitas pemahaman dalam pengelolaan hutan yang cukup baik dan juga kompetensi yang cukup baik.

4. Indikator otoritas dan diskresi: Memiliki kewenangan dan cukup memiliki diskresi dalam pengelolaan hutan

5. Indikator Geografis: menyelamatkan lebih banyak ekosistem sumberdaya hutan berupa flora dan fauna

6. Indikator Budaya: kondisi sosial budaya masyarakatnya yang memiliki keunikan dan ciri khas dari masyarakat suku sunda menjadi daya tarik pariwisata konservasi.

Adapun faktor penghambar kinerja implementasi kebijakan tata kelola hutan dapat dikemukakan, sebagai berikut:

1. Indikator kompleksitas kebijakan, dilihat dari faktor internal: Jumlah SDM Polisi Kehutanan, Penyuluh dan PEH serta sarana dan prasarana yang dibutuhkan belum memadai, sedangkan dari faktor eksternal: Masyarakat di disekitar TNGHS masih melakukan perambahan dalam bentuk penggarapan lahan/ pemanfaatan lahan (untuk pemukiman, lahan pertanian, kebun campuran), Illegaloging, PETI (pertambangan emas tanpa izin), dan perburuan liar (satwa dan fauna yang berekonomi tinggi), ada banyak villa yang sudah berdiri sejak kawasan hutan dikelola oleh pengelola sebelumnya. Adapun masalah lain seperti kurangnya komunikasi dan kordinasi yang baik antara Balai TNGHS dengan Masyarakat

2. Indikator Persepsi Manfaat kebijakan, dilihat dari kerugian bagi pengelolaan: menambah beban dalam pengelolaan hutan karena hutan yang mengalami perluasan tersebut terdapat masyarakat yang sudah sejak lama tinggal dan bermukim di kawasan hutan. sedangkan kerugian bagi masyarakat: adalah tidak diizinkan lagi menebang pohon/kayu untuk membuat rumah/ tempat ibadah dan tidak diizinkanya merambah lahan, melakukan perburuan flora dan fauna sehingga mereka kehilangan mata pencaharian tambahan.

3. Indikator SDM: Jumlah SDM yang belum sesuai dengan kebutuhan. Terutama jumlah pegawai lapangan seperti polisi kehutanan, Pengendali Ekosistem Hutan, dan Penyuluh yang masih kurang

4. Indikator Otoritas Dan Diskresi: adanya tumpang tindih kewenangan dengan tiga pemerintah daerah dan kewenangan kepala adat.

5. Indikator Geografis: berada di tiga wilayah administratif pemerintahan dan terdapat masyarakat yang sudah sejak lama tinggal dan bermukim di kawasan tersebut khususnya masyarakat adat yang berjumlah kurang lebih ada 11-12 kasepuhan.

6. Indikator Budaya: Kondisi sosial budaya yang masyarakat adat yang mengikuti wangsit untuk menggarap lahan di kawasan hutan.

Dengan demikian, tata kelola hutan dipengaruhi oleh berbagai faktor yatu kompleksitas, persepsi, otoritas dan diskresi, faktor geografis dan faktor budaya. Jika keenam faktor itu dijalankan dengan baik dan dipandang menjadi faktor pendukung, maka tata kelola hutan akan berjalan dengan baik.

\section{Proses Monitoring dan Evaluasi Hasil Kebijakan Perluasan TNGHS}

Dalam proses pemantauan dan evaluasi hasil kebijakan perluasan TNGHS, Balai TNGHS selaku pelaksana melakukan proses pemantauan dan evaluasi hasil kebijakan perluasan dan Perubahan fungsi hutan TNGHS dengan dilaksanakanya monitoring dan evaluasi kegiatan pengelolaan yang dalam penelitian ini dibatasi kegiatanya yaitu monitoring dan evaluasi masyarakat daerah penyangga dan monitoring dan evaluasi kelembagaan maupun sarana dan prasarana Balai TNGHS.

Berdasarkan hasilobservasi (pengamatan) dokumen/ laporan tahunan BTNGHS diketahui bahwa kegiatan pertama yang termasuk ke dalam strategi Balai TNGHS dalam mengimplementasikan kebijakan perluasan dan perubahan fungsi TNGHS adalah memonitoring dan mengevaluasi masyarakat daerah penyangga. Kegiatan ini dilaksanakan dengan tujuan untuk mendapatkan informasi perkembangan kegiatan pemberdayaan masyarakat dalam kelompok (MDK) atau Masyarakat Kampung Konservasi (MKK) TNGHS.

Ruang lingkup kegiatan ini adalah monitoring aktivitas pemberdayaan masyarakat dan perkembangannya 
yang meliputi peningkatan kapasitas SDM (sumberdaya manusia), pengembangan usaha ekonomi produktif dan pengembangan bina cinta alam dan lingkungan serta evaluasi mengenai dampak dan keberlanjutan kegiatan pemberdayaan masyarakat bagi kelompok/ masyarakat dan kawasan Taman Nasional Gunung Halimun Salak. Metode yang digunakan dalam pelaksanaan kegiatan monitoring dan evaluasi ini adalah dengan melakukan pertemuan kelompok serta melakukan cek lapangan.

Sasaran pelaksanaan monitoring evaluasi masyarakat desa penyangga adalah:

1. Seksi Pengelolaan Taman Nasional Wilayah I Lebak; MKK Lebak Sangka dan MKK Cikuning

2. Seksi Pengelolaan Taman Nasional Wilayah II Bogor: MKK Cisangku dan Kelompok Tani Mandiri 3. Seksi Pengelolaan Taman Nasional Wilayah III Sukabumi: Kelompok Kampung Konservasi Cililin dan MKK Sukagalih

Kegiatan pemberdayaan masyarakat melalui pembentukan MKK di nilai cukup berhasil dan perlu di kembangkan di tempat lainnya. Khususnya dalam penelitian ini kegiatan pemberdayaan masyarakat melalui pembentukan MKK di Kampung Sukagalih sebagai salah satu kelompok kampung konservasi di TNGHS. Berdasarkan pengamatan pada kelompok MKK, program yang di kembangkan memiliki pengaruh positif terhadap upaya pelestarian TNGHS karena dapat menimbulkan peran serta dan keterlibatan masyarakat secara aktif. Program MKK secara langsung maupun tidak langsung memiliki dampak positif secara ekonomi yang telah dirasakan oleh masyarakat atau pun anggota kelompok (Balai Taman Nasional Gunung Halimun Salak, 2014).

Berdasarkan hasil kegiatan monitoring dan evaluasi di kelompok MKK kampung sukagalih secara kelembagaan, pengelolaan kawasan hutan dan pemberdayaan masyarakat sudah berjalan dengan baik, namun masih diperlukan penguatan dan pembinaan terhadap kelompok.Program MKK secara langsung maupun tidak langsung memiliki dampak positif secara ekonomi yang telah dirasakan oleh masyarakat atau anggota kelompok (Balai Taman Nasional Gunung Halimun Salak, 2014).

Berdasarkan hasil monitoring dan evaluasi maka beberapa saran yang diperlukan adalah peningkatan sistem dukungan dan intervensi dari berbagai pihak harus ditingkatkan dalam rangka mengatasi permasalahan yang dihadapi kelompok seperti informasi pasar, peningkatan kapasitas masyarakat, selain itu perlu dilakukan pembinaan kelompok dan keberlanjutan program terhadap kelompok MKK yang sudah berjalan. Pemberian sanksi juga diperlukan terhadap kelompok MKK yang tidak konsisten yang hanya mengharapkan bantuan ekonominya saja tanpa ada kepedulian dan tanggung jawab terhadap kelestarian kawasan hutan. Diperlukan kegiatan peningkatan kapasitas terhadap anggota kelompok seperti pelatihan keterampilan dan budidaya. Keberlanjutan kegiatan pendampingan terhadap kelompok MKK dan rutinitas kegiatan monitoring dan evaluasi secara berkala dimaksudkan untuk mengetahui semua kendala dan permasalahan yang terjadi di kelompok (Balai Taman Nasional Gunung Halimun Salak, 2014).

Selanjutnya kegiatan monitoring dan evaluasi hasil kebijakan perluasan dan perubahan fungsi TNGHS yang berupa memonitoring capaian pelaksanaan kegiatan yang dilaksanakan Balai TNGHS dalam melakukan kegiatan monitoring dan evaluasi kelembagaan maupun sarana dan prasarana. Kegiatan tersebut menghasilkan informasi bahwa kuantitas dan kualitas personil yang ada hingga saat ini belum mencukupi kepentingan pengelolaan taman nasional, bila dibandingkan dengan kawasan dan permasalahan pengelolaan yang dihadapi. Apabila dilihat dari jumlah resort pengelolaan Taman Nasional yaitu sebanyak 17 resort dan pada masing-masing resort baru berkisar 2-3 orang sementara untuk mengelola kawasan secara optimal dibutuhkan minimal 5-6 orang pegawai (Balai Taman Nasional Gunung Halimun Salak, 2014).

Lebih lanjut kualitas dan kuantitas SDM yang memadai terkait dengan keahlian, keterampilan, dedikasi dan berjiwa kepeloporan diperlukan untuk meningkatkan optimalisasi pengelolaan taman nasional. Bahkan upaya pengelolaan taman nasional memerlukan ilmu dan teknologi yang tepat sesuai dengan keragaman potensi sumber daya alam dan ekosistem. Dengan demikian maka diperlukan peningkatan kuantitas dan kualitas SDM TNGHS untuk menunjang pengelolaan sehingga pengelolaan TNGHS dapat berjalan dengan optimal (Balai Taman Nasional Gunung Halimun Salak, 2014).

Adapun pembangunan dalam rangka memenuhi kebutuhan sarana dan prasarana (sarpras) pengelolaan dan pemanfaatan taman nasional saat ini masih belum memenuhi kebutuhan. Sarpras merupakan alat penunjang dalam pelaksanaan pengelolaan kawasan TNGHS. Namun demikian secara kualitas dan kuantitas masih belum memadai secara optimal. Dari segi kualitas beberapa sarana dan prasarana dimaksud sudah tidak layak pakai sehingga perlu perbaikan dan atau pergantian. Sementara dari segi kuantitas penambahan jumlah sarpras yang ada diharapkan mampu mendukung kinerja pengelolaan. Sarpras yang dirasakan perlu adalah pengadaan kantor resort, peralatan pengolah data yaitu PC untuk kantor Balai dan seksi, printer untuk di resort. Selain itu, pengadaan peta kerja juga diperlukan untuk menunjang aktifitas para personil di lapangan. Hal ini terkait pengolahan dan alur data/ informasi dari lapangan ke kantor balai dan sebaliknya. Selain itu beberapa kendaraan yang kemampuanya tidak maksimal mengingat kondisi medan yang 
harus dilewati di kawasan TNGHS dan sekitarnya (Balai Taman Nasional Gunung Halimun Salak, 2014)

\section{SIMPULAN}

Berdasarkan Implementasi Kebijakan Tata Kelola Hutan Taman Nasional Gunung Halimun Salak jika dilihat dari faktor kebijakan tergolong cukup baik/ sedang, hal ini berkaitan dengan proses implementasi kebijakan yang belum optimal dan masih ada masalah-masalah yang harus diselesaikan diantaranya permasalahan internal Balai TNGHS yaitu minimnya jumlah SDM khususnya jumlah polisi kehutanan dan belum memadainya jumlah sarana dan prasarana. Adapun masalah eksternal yang dihadapi Balai TNGHS yaitu masyarakat yang bermukim di dekat, didalam maupun disekitar TNGHS masih melakukan perambahan dalam bentuk penggarapan lahan baik untuk pemukiman, lahan pertanian, kebun campuran dan kebutuhan lainnya, illegalloging, PETI (Pertambangan Emas Tanpa Izin), dan Perburuan Liar (Perburuan satwa dan flora yang berekonomi tinggi), serta masih berdirinya banyak villa di gunung bunder yang sudah berdiri sejak kawasan hutan dikelola oleh PERUMPERHUTANI.

Kebijakan Perluasan TNGHS memberikan manfaat pada pengelolaan TNGHS yaitu mencegah kerusakan hutan dan memulihkan kembali kawasan hutan yang mengalami kerusakan. Adapun manfaat sosial ekonomi bagi masyarakat diantaranya masyarakat ikut serta dalam hubungan kemitraan dengan pihak lain, masih diizinkan mengelola HHBK, adanya bantuan kepada masyarakat berupa kambing, bangunan MCK (mandi cuci kakus), pupuk, bibit padi, dll. Adapun manfaat lain yaitu mendapatkan penghasilan tambahan dari rumah-rumah mereka yang dijadikan homestay, disewa oleh peneliti/wisatawan yang hendak berkunjung ke kawasan TNGHS.Kebijakan perluasan TNGHS juga memotivasi masyarakat untuk berpendidikan tinggi. Namun kebijakan perluasan tersebut juga memberikan kerugian bagi pengelolaan dan masyarakat. Kerugian itu berupa menambah beban dan tanggung jawab Balai TNGHS dalam mengelola hutan sehingga pengelolaan yang dilakukan saat ini belum seoptimal sebelum adanya kebijakan perluasan, dan kebijakan perluasan TNGHS juga cukup merugikan masyarakat karena masyarakat dilarang untuk merambah hutan lagi sebagai mata pencaharian dan masyarakat dilarang menebang kayu/pohon untuk membuat dan memperbaiki rumah mereka serta cukup membuat resah masyarakat dalam menjalankan aktivitas atau kegiatan.

Implementasi kebijakan tata kelola hutan Taman Nasional Gunung Halimun Salak jika dilihat dari Kapasitas Organisasi juga tergolong cukup baik/sedang. Hal ini berkaitan dengan kualitas pemahaman SDM yang sudah baik, namun jumlah SDM nya masih kurang .Adapun kompetensi SDM yang masih perlu ditingkatkan lagi kompetensi pendidikan dan keterampilan SDM-nya. Adapun kemampuan Otoritas dan diskresi Balai TNGHS yang sejauh ini bisa dikatakan cukup mampu mengatasi permasalahan kebijakan karena ada program pengelolaan yang telah mereka lakukan namun masih perlu dievaluasi kembali komunikasi dan kordinasi secara keseluruhan yang dijalin dengan pemerintah daerah maupun masyarakat khususnya masyarakat adat yang sampai saat ini hubunganya kurang harmonis dengan Balai TNGHS sehingga sampai saat ini bisa dikatakan belum terjalinnya kerjasama yang baik antara Balai TNGHS dengan pemerintah daerah maupun masyarakat dalam pengelolaan hutan.

Implementasi kebijakan tata kelola hutan Taman Nasional Gunung Halimun Salak jika dilihat dari faktor lingkungan juga tergolong cukup baik / sedang. Hal ini berkaitan dengan situasi geografis dan kondisi sosial budaya yang cukup menghambat pengelolaan TNGHS dikarenakan adanya jumlah pemerintah daerah yang lebih dari 1 sehingga belum optimalnya kordinasi yang baik dengan ketiga pemerintah daerah tersebut. Situasi geografis yang meliputi tiga kabupaten ini juga memiliki banyak kampung dengan masyarakat dengan latar belakang/kepribadian berbeda-beda dari setiap daerah yang berdekatan dan berinteraksi langsung dengan kawasan TNGHS. Adapun hambatan lain yaitu kondisi sosial budaya masyarakat, khususnya masyarakat adat yang mengikuti wangsit untuk menggarap lahan di kawasan hutan. Namun, situasi geografis dan kondisi sosial budaya juga cukup mendukung dan berkontribusi terhadap pengelolaan TNGHS hal ini dikarenakan situasi geografis tersebut mampu menyelamatkan dan melindungi lebih banyak keanekaragaman hayati yang ada di kawasan hutan yang berada di tiga kabupaten tersebut. Adapun kondisi sosial budaya masyarakat TNGHS yang cukup berkontribusi terhadap pengelolaan hutan TNGHS.

\section{DAFTAR PUSTAKA}

Adimiharja, K. (1992). Kasepuhan Yang Tumbuh di Atas yang Luruh. Bandung: PT. Tarsito.

Balai Taman Nasional Gunung Halimun Salak. (2014). Laporan Tahunan, Tahun 2014. Sukabumi.

Bappenas (2007). Laporan Akhir Direktorat Kawasan Khusus dan Daerah Tertinggal Kementerian Negara Perencanaan Pembangunan nasional.

Dunn, W. N. (2003). Pengantar Analisis Kebijakan Publik. Yogyakarta: Gadjah Mada University Press.

Grindle, M. S. (1980). Politics and Policy Implementation in The Third World. New Jersey: Princnton 
University Press.

Purwanto, E.A. \& Sulistyastuti., D.R. (2012). Implementasi Kebijakan Publik.Konsep dan Aplikasinya di Indonesia. Yogyakarta: Gava Media.

Rahmawati, R., Salbiah, E. \& Pratidina, G. (2016). Pedoman Pariwisata Budaya: Mengenal Masyarakat Kasepuhan Sinar Resmi Taman Nasional Gunung Halimun Salak (II). Bogor: Unida Press.

Rahmawati, R. (2013). Konflik-Konflik Sumberdaya Hutan Di Jawa Barat Dan Kalimantan Barat, Indonesia. IPB University.

Rahmawati, R., Pratidina, G. \& Muarif. (2011). Strategi Adaptasi Ekologis Dan Pengentasan Kemiskinan Pada Masyarakat Sekitar Taman Nasional Gunung Halimun Salak. Sosial Humaniora, 2, (1), 26-43.

Rosalia, F. \& Ratnasari, Y. (2016). Analisis Pengelolaan Hutan Kemasyarakatan Di Sekitar Kawasan Hutan Lindung Register 30 Kabupaten Tanggamus Provinsi Lampung Tahun 2010. Sosiohumaniora,
$18,(1), 32-36$.

Siregar, B. (1993). Metode Riset Sosial. Jakarta: CV Kurnia.

Sjoraida, D.F. (2015). Implementasi Kebijakan Keterbukaan Informasi Publik Pada Pemerintah Provinsi Jawnformasi Publik Pada Pemerintah Provinsi Jawa Barat. Sosiohumaniora, 18, (3), 213-220.

Subadi. (2010). Penguasaan dan penggunaan Tanah Kawasan Hutan. Jakarta: PT.Prestasi Pustaka Karya.

Sugiyono. (2013). Metode Penelitian Administrasi. Bandung: ALFABETA.

Winarno, B. (2014). Kebijakan Publik: Center Of Academic Publishing Service (CAPS). Jakarta: PT.Buku Seru.

Yani, A. T. (2012). Wajar Kebijakan Publik. Bandung: Humaniora. 